\title{
On the edge: assessing fish habitat use across the boundary between Pacific oyster aquaculture and eelgrass in Willapa Bay, Washington, USA
}

\author{
Kelly A. Muething ${ }^{1, *}$, Fiona Tomas ${ }^{2,3}$, George Waldbusser ${ }^{1}$, Brett R. Dumbauld ${ }^{4}$ \\ ${ }^{1}$ College of Earth, Ocean, and Atmospheric Sciences, Oregon State University, Corvallis, OR 97331, USA \\ ${ }^{2}$ Instituto Mediterráneo de Estudios Avanzados (IMEDEA), 07190 Esporles, Illes Balears, Spain \\ ${ }^{3}$ Department of Fisheries and Wildlife, Oregon State University, Corvallis, OR 97331, USA \\ ${ }^{4}$ Agricultural Research Service, United States Department of Agriculture, Newport, OR 97365, USA
}

\begin{abstract}
Estuaries are subject to diverse anthropogenic stressors, such as shellfish aquaculture, which involve extensive use of estuarine tidelands. Pacific oyster Crassostrea gigas aquaculture is a century-old practice in US West Coast estuaries that contributes significantly to the regional culture and economy. Native eelgrass Zostera marina also commonly occurs in intertidal areas where oyster aquaculture is practiced. Eelgrass is federally protected in the USA as 'essential fish habitat', restricting aquaculture activities within or near eelgrass. To contribute scientific information useful for management decisions, we sought to compare fish habitat use of oyster aquaculture and eelgrass, as well as the edges between these 2 habitats, in Willapa Bay, Washington, USA. Furthermore, given a recent shift towards off-bottom culture methods, in part to protect seagrasses, long-line and on-bottom oyster aquaculture habitats were compared. A combination of direct (underwater video, minnow traps) and indirect (predation tethering units, eelgrass surveys) methods were employed to characterize differences in fish habitat use. Eelgrass density declined within both aquaculture habitats but less so within long-line aquaculture. Most fish species in our study used long-line oyster aquaculture and eelgrass habitats similarly with minimal edge effects, and on-bottom aquaculture was used less than either of the other 2 habitat types. These results are consistent with previously observed positive relationships between fish abundance and vertical habitat structure, but also reveal species-specific behavior; larger mesopredators like Pacific staghorn sculpins were sighted more often in aquaculture than in interior eelgrass habitats.
\end{abstract}

KEY WORDS: Oyster aquaculture $\cdot$ Eelgrass $\cdot$ Habitat $\cdot$ Edge effects

\section{INTRODUCTION}

As intersections of terrestrial, freshwater, and marine systems, estuaries provide a wide array of ecosystem services and have helped to support flourishing human populations for centuries (Costanza et al. 1997, Lotze et al. 2006). Along the West Coast of the USA, estuarine tidelands have been used extensively for shellfish production, beginning with harvest of native oysters Ostrea lurida by native Americans for

\footnotetext{
*Corresponding author: kamuething@gmail.com
}

millennia and by European immigrants since the mid 1800 s, shifting towards the current culturing of Pacific oysters Crassostrea gigas in the 1920s (Baker 1995, Lindsay \& Simons 1997, Robinson 1997, Shaw 1997). Shellfish aquaculture is an economically important practice that supports a diverse industry and provides seafood for people across the country. In Washington State alone, commercial aquaculture of Pacific oysters brought in \$32.4 million in 2016 (NMFS 2016). Currently, aquaculture within the USA

(C) K. Muething, F. Tomas, G. Waldbusser, and outside the USA the US Government 2020. Open Access under Creative Commons by Attribution Licence. Use, distribution and reproduction are unrestricted. Authors and original publication must be credited. 
amounts to just $5 \%$ of the seafood consumed domestically (NOAA 2011), highlighting the potential for expansion of shellfish aquaculture to help meet this domestic trade gap and rising demand. However, growth of shellfish production is currently partly restricted by regulations put in place to limit potential impacts of aquaculture on other managed estuarine resources and protect other human interests within these estuaries.

Seagrasses provide a variety of ecosystem services and have been globally recognized as important foundation species and ecosystem engineers (Jones et al. 1994, Costanza et al. 1997). These services include coastal protection, global carbon sequestration, and improved water quality (Orth et al. 2006). Most relevant to the current study is their role in providing nursery habitat for juvenile fish and invertebrates (Beck et al. 2001, Heck et al. 2003, Orth et al. 2006, Nagelkerken et al. 2015, Sheaves et al. 2015). The native eelgrass Zostera marina of the US West Coast provides habitat for early life stages of commercial species like salmonids, Dungeness crab, rockfish, and English sole (Rooper et al. 2003, Holsman et al. 2006, Dumbauld et al. 2015, Olson et al. 2019). This clear but indirect connection between eelgrass and the economic success of fisheries is the reason for its protection in the USA as 'essential fish habitat' under the Magnuson-Stevens Fishery Conservation and Management Act (16 USC §§18011891d). This designation prohibits the damage or destruction of eelgrass and forces consideration of trade-offs with the permitting of other interests, such as shellfish aquaculture. Under current regulations implemented by the Pacific Fishery Management Council, existing aquaculture is generally permitted to continue as practiced, but new aquaculture is prohibited within 25-30 feet (7.6-9.1 m) of existing eelgrass beds (Pacific Fishery Management Council 2014).

Eelgrass and oyster aquaculture occur at similar tidal elevations and often overlap within relatively large areas in US West Coast estuaries (Dumbauld \& McCoy 2015). While these 2 habitats are not mutually exclusive, aquaculture practices can sometimes limit the extent of eelgrass (Wisehart et al. 2007, Tallis et al. 2009, Wagner et al. 2012, Skinner et al. 2013). Oyster aquaculture can result in both longterm disturbances, such as the addition of oysters and associated gear, and short-term disturbances, like harvest or maintenance events, that can impact the quantity and quality of eelgrass habitat within estuaries (Simenstad \& Fresh 1995, Dumbauld et al. 2009). Characterization of habitat use of both oyster aquaculture and eelgrass could help to further inform future management decisions and marine spatial planning concerning potential conflicts between these 2 uses.

Estuarine habitats with more habitat structure have generally been shown to support higher faunal abundances and diversity (Orth et al. 1984, Jenkins et al. 1997, Heck et al. 2003). Eelgrass provides such a natural biogenic structure and has been widely documented to harbor a more diverse assemblage of organisms compared to unvegetated areas (Ferrell \& Bell 1991, Pinnix et al. 2005, Hosack et al. 2006, Ferraro \& Cole 2007, Gross et al. 2017). Oysters and oyster aquaculture also create structured habitat that generally supports a higher diversity and abundance of organisms than adjacent open mudflat (Castel et al. 1989, Pinnix et al. 2005, Hosack et al. 2006, Ferraro \& Cole 2007). While higher densities of benthic invertebrates have been found in eelgrass than in oyster aquaculture beds, the abundance of fish and other mobile nekton has largely been shown to be similar or even greater within aquaculture beds (DeAlteris et al. 2004, Pinnix et al. 2005, Hosack et al. 2006).

Importantly, the arrangement of different habitats at landscape spatial scales (100s-1000s of $\left.\mathrm{m}^{2}\right)$ also affects the distribution of organisms (Forman \& Godron 1986, Turner 1989, Wiens \& Milne 1989), but this approach has rarely been taken when examining seagrass-aquaculture interactions. Furthermore, edges or boundaries between habitats, which may result in abrupt changes in resource availability, refugia, and predation pressure, can strongly influence the abundance and diversity of organisms (Gates \& Mosher 1981, Sisk \& Haddad 2002, Ewers et al. 2007). In marine ecosystems, seagrasses have been a focal system for research on edge effects because of their natural propensity to form discrete patches (Boström et al. 2006, 2011). Patterns of faunal abundance are complicated at these habitat edges, where greater densities of organisms can occur compared to the core habitat (Bologna \& Heck 2002, Tanner 2005, Smith et al. 2008), yet the opposite relationship has also been reported (Bell et al. 2001, Jelbart et al. 2006). Inconsistent seagrass edge effects could be related to several factors including species characteristics (Eggleston et al. 1998, Smith et al. 2010), patch size (Bowden et al. 2001, Smith et al. 2010), habitat complexity (Hovel \& Lipcius 2001, Pinna et al. 2013), body size and life stage of organisms (Hovel \& Lipcius 2001, Selgrath et al. 2007), and the sharpness of the habitat transition (Matias et al. 2013). These factors in turn influence the strength of edge effects by changing resource availability and predation 
pressure. Due to the propensity of oyster aquaculture and eelgrass to overlap and regulatory constraints placed on expansion of shellfish operations to avoid this overlap, edge effects between these 2 habitats are a pertinent question for managers of US West Coast estuaries. Furthermore, growth of the oyster aquaculture industry could mean an increase in the number or size of aquaculture/eelgrass boundaries. Thus, information about use of the edge habitat between aquaculture and eelgrass is necessary to inform management and regulation.

Investigation into the impact of edges between aquaculture and eelgrass beds on faunal abundance is further complicated by the wide range of aquaculture methods used in US West Coast estuaries. These methods differ in many characteristics, including the habitat structure created and harvest method. To date, research has focused on on-bottom (OB) culture methods, because this has historically been the primary technique for growing oysters in most estuaries along the US West Coast (Dumbauld et al. 2009). However, off-bottom culture is becoming increasingly popular due to regulatory constraints and market trends. This method can result in a higher-quality product for the half-shell market (Walton et al. 2012) and has also been shown to reduce some impacts to eelgrass, as disturbance due to mechanical harvesting is reduced (Tallis et al. 2009, Ferriss et al. 2019). The ecological impacts of such practices, where cages, floats, rafts, lines, and supporting structures are also placed in the estuary, are less well-understood. The habitat provided by these new types of aquaculture is distinct from that provided by oysters alone in $\mathrm{OB}$ aquaculture. Comparing OB aquaculture habitat with habitat created by off-bottom aquaculture provides additional information about the impact of this industry on the estuarine habitat matrix.

In this study, we explored the similarities and differences between fish habitat use of oyster aquaculture and eelgrass by addressing 2 main questions: (1) Do oyster aquaculture and eelgrass habitats support different abundances of fish, and is there an associated effect at the edge between these habitats? (2) Does the aquaculture method affect the difference seen amongst habitats (if any)? Together, these questions were designed to provide an ecological basis for an integrated framework of management regulations related to the overlap of eelgrass and oyster aquaculture in US West Coast estuaries.

Ecological theory suggests that habitat structure increases faunal abundance and diversity (Orth et al. 1984, Jenkins et al. 1997, Heck et al. 2003). We posited that differences between aquaculture and eelgrass habitats might only be detectable for OB culture since it provides less vertical structure than eelgrass. In contrast, off-bottom aquaculture habitat might support comparable faunal abundances to those found in eelgrass habitat due to the similarity in vertical habitat structure. Because edge effects typically occur in locations with food-risk tradeoffs (Macreadie et al. 2010, 2012, Smith et al. 2011), we anticipated 3 potential trends in abundance at the aquaculture-eelgrass edge: (1) fish abundance could be enhanced if food resources were enhanced, yet risks of being preyed upon were not, (2) fish abundance could be decreased if risks of being preyed upon were higher, and (3) no difference might be observed if both bordering habitats had similar effects. Again, based on the amount of structure in each habitat, we expected edge effects to be most apparent between OB culture and eelgrass. By investigating use of the transition between aquaculture and eelgrass habitats, a more informed and balanced management approach can be reached.

\section{MATERIALS AND METHODS}

\subsection{Study sites}

Willapa Bay is a macrotidal estuary located in southwestern Washington State, USA $\left(46.5395^{\circ} \mathrm{N}\right.$, $123.9888^{\circ} \mathrm{W}$ ). It is the third largest estuary on the US Pacific Coast, with an area of $358 \mathrm{~km}^{2}$. The bay is strongly tidally influenced, with about $60 \%$ of the total area $\left(215 \mathrm{~km}^{2}\right)$ considered intertidal (Hedgpeth \& Obrebski 1981, Dumbauld \& McCoy 2015). Of that $215 \mathrm{~km}^{2}, 8 \%$ is devoted to oyster aquaculture $\left(17 \mathrm{~km}^{2}\right)$ and recent surveys have shown that Zostera marina occupies approximately $32 \%$ of the tide flat (60-80 km²) (Dumbauld \& McCoy 2015). Eelgrass substantially overlaps with oyster aquaculture (13\%) and is often found at similar tidal elevations (Ruesink et al. 2006, 2010). OB oyster aquaculture involves spreading oysters set on cultch across the tideflat and harvesting either by dredging or by hand after approximately $3-5 \mathrm{yr}$ of grow-out. The method of offbottom aquaculture primarily used in Willapa Bay is long-lines (LLs), where oysters are woven into a line that is stretched in rows across the tideflat and suspended on PVC pipe about $0.5 \mathrm{~m}$ off the bottom. Our sampling of off-bottom aquaculture habitat focused on this method.

Sampling was undertaken at 3 sites within the bay (Fig. 1): Russell Channel $\left(46.65705^{\circ} \mathrm{N}, 123.94678^{\circ} \mathrm{W}\right)$, Tokeland $\left(46.71718^{\circ} \mathrm{N}, 123.94484^{\circ} \mathrm{W}\right)$, and Nemah 


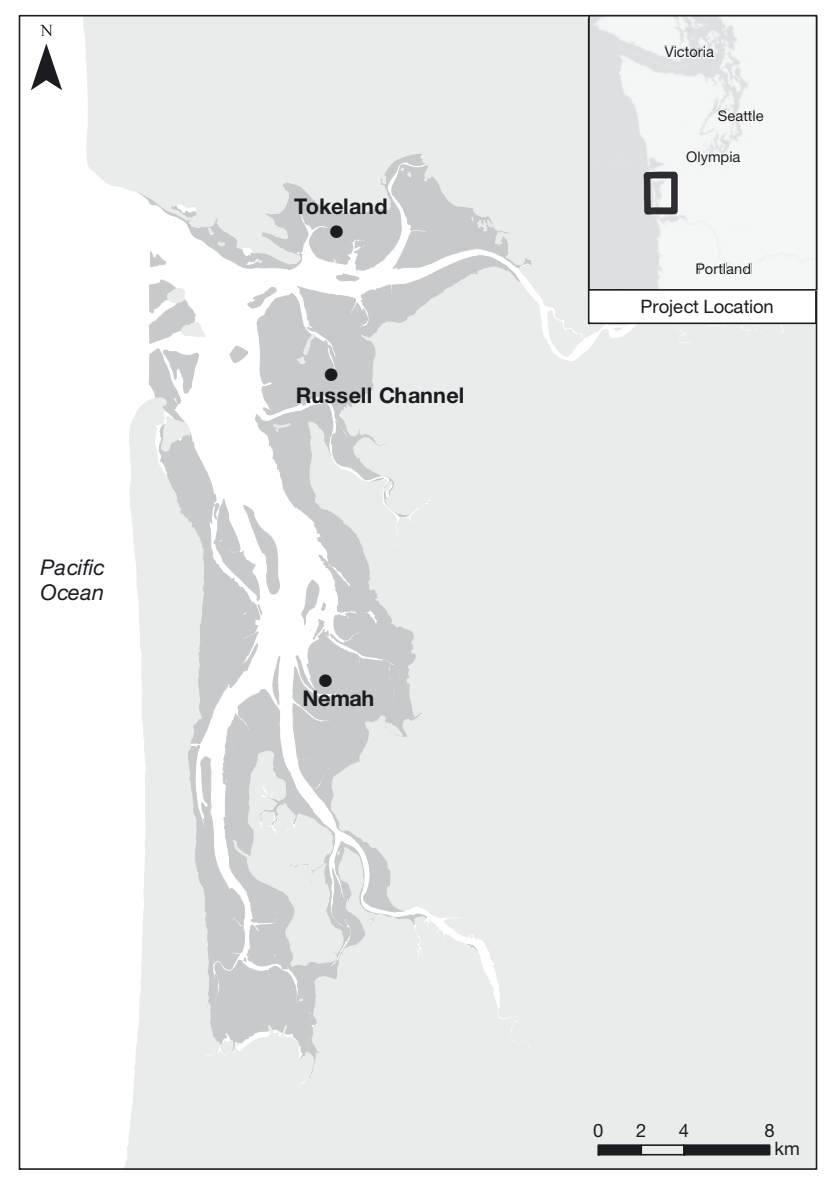

Fig. 1. Sampling sites within Willapa Bay, Washington, USA. Each site included off-bottom and on-bottom aquaculture adjacent to an established eelgrass bed

$\left(46.52833^{\circ} \mathrm{N}, 123.94814^{\circ} \mathrm{W}\right)$. These sites were chosen based on 4 factors: (1) presence and appropriate configuration of necessary habitats (OB aquaculture, LL aquaculture, and eelgrass), (2) similar tidal elevation within each site, (3) structural consistency of oyster and eelgrass habitats (e.g. similar density of eelgrass, similar size of oysters), and (4) accessibility at low and high tide. Sampling was undertaken twice at each site: once in July 2017, and a second time approximately $4 \mathrm{wk}$ later in August 2017. Sampling was constrained to the summer months to target the season with peak eelgrass density and also fish abundance and diversity (Orth \& Moore 1986, Thom et al. 2003, Hosack et al. 2006, Ruesink et al. 2010, Zhang et al. 2016, Gross et al. 2019).

\subsection{Sampling design}

Samples were taken along a $60 \mathrm{~m}$ transect that was set up perpendicular to the boundary between the aquaculture and eelgrass habitats at each site. This transect was aligned parallel to the nearest channel when possible. At one site (Russel Channel), eelgrass density did not allow for this directionality, resulting in a slightly larger elevation gradient along the transect than at the other 2 sites. An array of sampling methods was used to characterize the differences in species presence and behavior at each of 5 , evenly spaced positions (15 $\mathrm{m}$ apart) along the transect (Fig. 2). These 5 positions were considered to represent different parts of the habitat matrix: (A) aquaculture interior, (B) aquaculture intermediate, (C) edge, (D) eelgrass intermediate, and (E) eelgrass interior. The edge was defined as the point where aquaculture ceased. This was straightforward for LLs (simply where the culture lines ended). For OB aquaculture, however, the edge was more diffuse and was designated by visually assessing the location where the density of oysters dramatically decreased. The edge was always the middle of the transect, so the interior habitats were each located $30 \mathrm{~m}$ into the respective habitat.

\subsubsection{Environmental data}

Four HOBO ${ }^{\circledR}$ Onset Data Loggers UA-002-64 were used to measure water temperature $\left({ }^{\circ} \mathrm{C}\right)$. One logger was attached to a minnow trap (Fig. 2) deployed in the interior of each aquaculture bed, the interior of the eelgrass bed, and the edge along the LL transect (4 loggers total at each site). Loggers recorded data at 15 min intervals and were used to assess environmental differences in temperature between sites.

\subsubsection{Eelgrass sampling}

Eelgrass metrics were collected every $3 \mathrm{~m}$ along each transect, resulting in a total of 21 data points at each site. At each sampling location, a $0.0625 \mathrm{~m}^{2}$ quadrat was used to assess percent cover and shoot density of $Z$. marina. Eelgrass morphology was measured on 10 eelgrass shoots from each of the 5 main sampling positions along the transect. These shoots were placed in a cooler and stored at $-20^{\circ} \mathrm{C}$ until processing. The length and width of the longest blade and epiphyte load (dry mass of epiphytes / dry mass shoot) were measured (Hayduk et al. 2019). Length and width were then multiplied together to determine blade surface area. Length was defined as the distance from the last nodule on the rhizome to the end of the blade. Width was measured at the center 


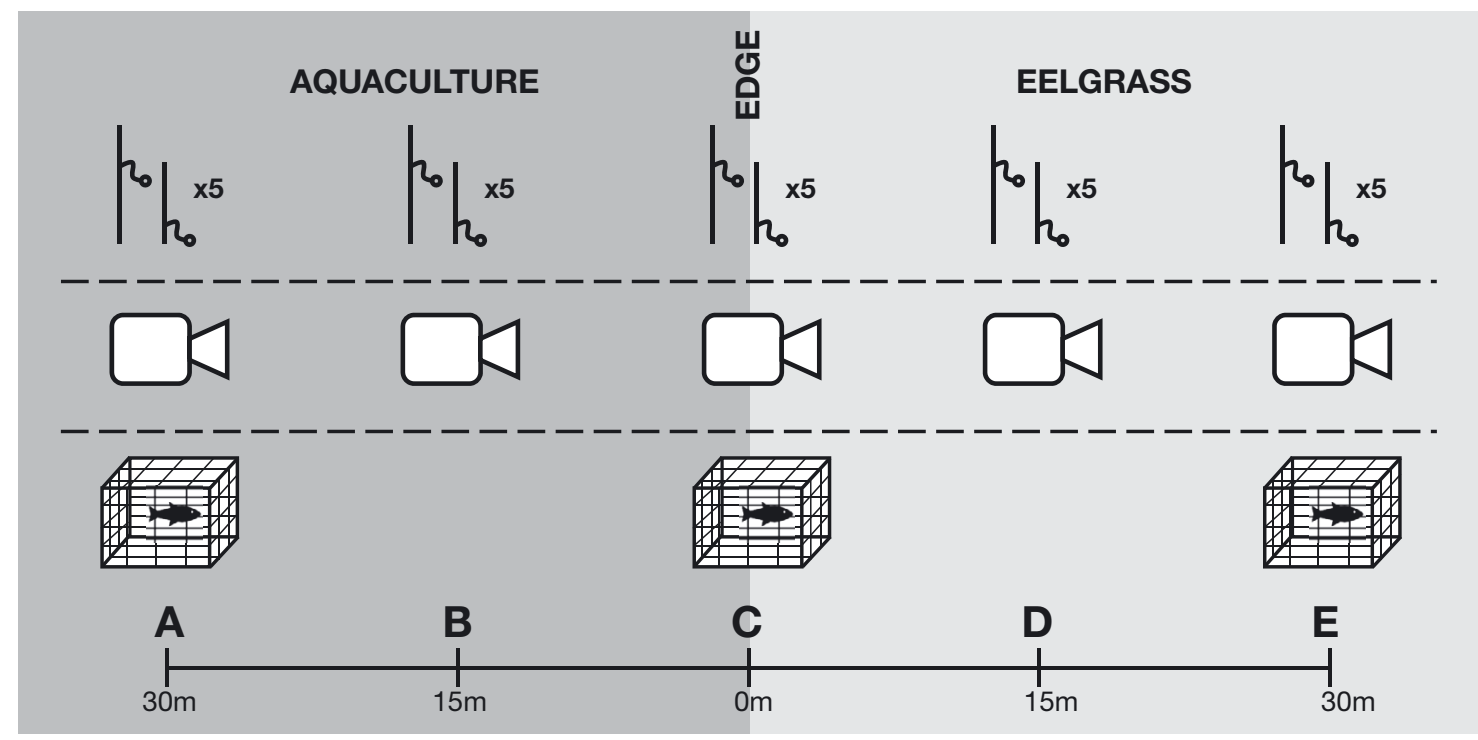

Fig. 2. Sampling design showing predation tethering units (top), cameras (middle), and minnow traps (bottom). Letters refer to main habitat points along the transect (A: aquaculture interior; B: aquaculture intermediate; C: edge; D: eelgrass intermediate; E: eelgrass interior)

of the blade's length. Epiphyte load was determined by scraping the epiphytes off the blade using a microscope slide and then drying the blades and epiphytes separately in an oven at $60^{\circ} \mathrm{C}$ for $48 \mathrm{~h}$ or until a constant weight was reached (Hayduk et al. 2019). To estimate the total epiphyte biomass across the transect for analysis, epiphyte load was multiplied by shoot density. Blade surface area was also multiplied by shoot density to approximate emergent surface area across the transect.

\subsubsection{Digital video}

Digital video data was gathered using GoPro HERO $4{ }^{\circledR}$ cameras placed at each of the 5 main positions along the transect (Fig. 2). Camera mounts were constructed out of 1" $(2.5 . \mathrm{cm})$ PVC pipe, which included an arm for the camera and a $0.25 \mathrm{~m}^{2}$ quadrat that lay on the bottom (Fig. S1 in the Supplement at www.int-res.com/articles/suppl/q012p541_ supp.pdf). The camera was affixed approximately $30 \mathrm{~cm}$ off the bottom and a makeshift Secchi disk was mounted on one corner of the quadrat, approximately $1 \mathrm{~m}$ away from the camera. The Secchi disk was used for a quantitative analysis of the visibility in the video using image analysis software. Its placement also acted as a point of reference beyond which organisms were not counted.

The cameras were deployed by snorkeling out to a buoy that had been placed at low tide and were retrieved from a boat approximately $2 \mathrm{~h}$ after deployment (when the cameras ran out of battery).

\subsubsection{Predation tethering units}

Predation intensity was measured with predation tethering units (PTUs) (Duffy et al. 2015, Reynolds et al. 2018). PTUs are used widely in a variety of systems to estimate how much predation is occurring within a given habitat or area. Bamboo stakes with small pieces of dried squid attached as bait were placed at the 5 main positions along the transect, and the presence or absence of the squid was recorded at predetermined time points. Two different PTU treatments ('high' and 'low') were deployed. Dried squid bait (diameter $=0.5 \mathrm{in}[1.27 \mathrm{~cm}]$ ) was superglued to a $10 \mathrm{~cm}$ monofilament line and tied at $30 \mathrm{~cm}$ above the substrate for the high treatment and $10 \mathrm{~cm}$ above the substrate for the low treatment, so that the bait was suspended $20 \mathrm{~cm}$ above and just above the substrate, respectively. These 2 treatments were designed to assess different types of predators: those within the water column and those that were searching for prey along the bottom. Five PTUs of each treatment were deployed opposite the traps (Fig. 2) at each position at low tide. The stakes were placed in 2 rows approximately $2 \mathrm{~m}$ apart, alternating high and low treatment within each row starting at about $4 \mathrm{~m}$ from the transect tape, so as to not influence other sampling techniques. Presence of the squid bait was checked 
once the water had reached a depth of about $30 \mathrm{~cm}$ and then again approximately $24 \mathrm{~h}$ later.

\subsubsection{Minnow traps}

Minnow traps (approximately $60 \times 60 \times 46 \mathrm{~cm}$, with a $\sim 15 \mathrm{~mm}$ opening) were used to sample the fish species and were placed about 5-6 $\mathrm{m}$ from the transect tape opposite the PTUs at each of 3 transect positions: A, C, and E (Fig. 2). Traps (un-baited) were deployed at low tide and retrieved approximately $1 \mathrm{~h}$ after the local high tide. Captured fish were identified to species (where possible), counted, measured, and then returned to the water.

\subsection{Video processing}

Video footage was first assessed for visibility using the difference in the pixel values between the black and white quadrants of the Secchi disk. As turbidity increases, the contrast between these 2 sections of the image should decrease to zero. ImageJ (https:// imagej.nih.gov/ij/index.html; Schindelin et al. 2015) was used to assess the contrast in a still photo taken every $20 \mathrm{~min}$ from each $2 \mathrm{~h}$ video $(\mathrm{n}=5)$. Within the software, a horizontal line was drawn from one quadrant of the disk to the other and the grayscale values along this line were exported. The minimum and maximum of the second derivative of the curve were determined and used as the bounding points of the quadrants to obtain average values for the white and black sections of the Secchi disk. These averages were then subtracted to get a contrast for the given image. Grayscale pixel values are assessed on a range from zero (black) to 255 (white), so a maximum contrast would be 255, although this value would not be realistic in natural conditions. In some cases, eelgrass limited the view of the Secchi disk, so as many measurements as possible were made. Only 2 videos did not have any usable images. The average of the calculated contrast values provided a water clarity score for each video. Obstruction by eelgrass or macroalgae was also assessed at each 20 min time point and the video was given an average score based on the percentage of the field-of-view that was blocked. The frame was roughly divided into thirds, and obstruction was assessed in these increments. Correlation between visibility and the number of fish seen was tested using these scores prior to running statistical analyses.

Analysis of the species composition and behavior within each video was completed using BORIS, a free behavioral coding software (Friard \& Gamba 2016). Previous experience with video quality suggested that the middle hour of video was appropriate for analysis (Clarke 2017). Thus, observation began at $30 \mathrm{~min}$ into the recording and ended at $1.5 \mathrm{~h}$. Within the software, any fish or crab sighting was logged with the species identification and behavior category. Clarke (2017) described 4 behavior categories that were applied to each fish or crab sighted: transit (movement through the frame with no other detectable behaviors), forage (action to ingest or seek out food), school (2 or more fish of the same species moving together, sensu Keenleyside 1955), and refuge (using structure to hide from predators). Because it was difficult to know if an individual reentered the frame once it had left, our response variable is termed as 'sightings', rather than counts. For individuals whose species was unidentifiable, the observation was recorded as such and included in the calculation of total sightings. All videos were watched by the same individual to decrease observer bias. Due to issues with video quality and inconsistencies in the camera gear used for video data collection between the 2 sampling trips, only video from the August 2017 trip was included in this analysis (30 videos, $2 \mathrm{~h}$ each).

\subsection{Statistical analyses}

All data analyses were completed using R v.3.3.1 (R Core Team 2016). Generalized linear mixed models (GLMMs; Bolker et al. 2009) were fit to assess the significance of the position along the transect and aquaculture type for each response variable (see Table 1). Both transect position (i.e. the sampling position along the transect between oyster aquaculture and eelgrass habitats; 5 levels: A, B, C, D, or E) and aquaculture type (2 levels: LL or OB) were treated as categorical fixed effects. When data were available for both time points, sampling date was included as a random effect (2 levels: July or August). Thus, the data structure was a 2-factor design with 3 replicates (site) and a random effect of date $(n=3)$. These models were fit using the 'lme4' package (Bates et al. 2015). After checking the reasonability of assumptions by examining residuals and leverage of the data, all data (eelgrass survey parameters, epiphyte load, etc.) were fit using a Gaussian distribution, except for PTU, minnow trap, and video sighting data. Count data from the minnow traps and video were fit using a Poisson distribution. Presence/ absence data from the PTUs were analyzed using logistic regression with 2 additional fixed effects: 
treatment (2 levels: high and low) and check time (2 levels: first and $24 \mathrm{~h}$ ). GLMM analysis was followed with a Type II Wald $\chi^{2}$-test (analysis of deviance) using the Kenward-Roger degrees of freedom approximation to assess overall significance of the factors (Schaalje et al. 2002). Because video data were only available for one timepoint, models were run without the random effect of date.

When the interaction term between transect position and aquaculture type was significant in the original model, multiple pairwise comparisons were completed to explore factors driving the significant interaction. Simultaneous $z$-tests were run to examine all pairwise comparisons between the 10 habitats (LL-A, OB-A, LL-B, etc.) using the 'multcomp' package (Hothorn et al. 2008, Wright et al. 2014). Comparisons of interest included those between the edge and other habitats within each aquaculture type, in addition to differences between the aquaculture types at each transect position. Although all pairwise comparisons were made, only significant comparisons of interest are indicated in associated figures to highlight these differences.

\section{RESULTS}

\subsection{Eelgrass survey and environmental data}

Both percent cover and shoot density of Zostera marina varied with transect position and the interaction term between transect position and aquaculture type (Tables 1 \& S1-S4, Fig. S2). Post hoc analyses (Table S2) indicated that eelgrass percent cover in the 2 eelgrass habitats on the LL transect (LL-D and LL-E) was significantly greater than that on the LL edge (LL-C) by a factor of about 2 (i.e. approximately 50 vs. $25 \%$ ). Eelgrass cover in the OB eelgrass habitats (OB-D and OB-E) was also significantly greater than that at the edge (OB-C) by a factor of 2 (Table S2). Within the OB aquaculture, the intermediate habitat (OB-B) harbored significantly less eelgrass than the OB edge (OB-C; Table S2). Similar patterns were seen in post hoc analyses of the shoot density data (Table S4); shoot densities in the eelgrass habitats along the OB transect (OB-D and OB-E) were significantly greater (averaging about 70 shoots $\mathrm{m}^{-2}$ ) than those at the OB edge (OB-C; with mean density of 20 shoots $\mathrm{m}^{-2}$ ), but there was no significant difference between density in these habitats on the LL transect (Table S4). Shoot density at the LL edge (LL-C) differed significantly from density in the aquaculture habitat $30 \mathrm{~m}$ from the edge (LL-A), showing an average shoot density about 4 times higher than in the interior of the aquaculture bed (Table S4). The 2 aquaculture types also differed in shoot density at the intermediate eelgrass habitat (D) (Table S4).

Blade surface area varied significantly with transect position, aquaculture type and their interaction (Table 1). Post hoc analyses indicated a significant difference in blade area between the LL edge (LL-C) and LL eelgrass habitat $30 \mathrm{~m}$ from the edge (LL-E), as well as between the 2 aquaculture types at the eelgrass interior (OB-E and LL-E; LL-C and LL-E:

Table 1. Analysis of deviance tests following generalized linear mixed models on eelgrass Zostera marina presence and structure, minnow trap data, and digital video data metrics. $\mathrm{N}=3$ for all tests. ${ }^{*} \mathrm{p}<0.05$

\begin{tabular}{|c|c|c|c|}
\hline \multirow{2}{*}{ Metric } & \multirow[b]{2}{*}{$\begin{array}{l}\text { Transect } \\
\text { position }\end{array}$} & \multirow{2}{*}{$\begin{array}{c}\text { Fixed effect } \\
\text { Aquaculture } \\
\text { type }\end{array}$} & \multirow[b]{2}{*}{ Interaction } \\
\hline & & & \\
\hline \multicolumn{4}{|l|}{ Eelgrass (Z. marina) } \\
\hline Percent cover & $\begin{array}{c}\chi^{2}(4)=240.54 \\
p<0.001^{*}\end{array}$ & $\begin{array}{c}\chi^{2}(1)=0.00 \\
p=0.952\end{array}$ & $\begin{array}{c}\chi^{2}(4)=13.08 \\
p=0.011^{*}\end{array}$ \\
\hline Shoot density & $\begin{array}{c}\chi^{2}(4)=104.70 \\
p<0.001^{*}\end{array}$ & $\begin{array}{c}\chi^{2}(1)=0.26 \\
p=0.610\end{array}$ & $\begin{array}{c}\chi^{2}(4)=25.14 \\
p<0.001^{*}\end{array}$ \\
\hline Blade surface area & $\begin{array}{c}\chi^{2}(4)=25.80 \\
p<0.001^{*}\end{array}$ & $\begin{array}{c}\chi^{2}(1)=15.11 \\
p<0.001^{*}\end{array}$ & $\begin{array}{c}\chi^{2}(4)=12.56 \\
p=0.014^{*}\end{array}$ \\
\hline Epiphyte load & $\begin{array}{c}\chi^{2}(4)=7.69 \\
p=0.104\end{array}$ & $\begin{array}{c}\chi^{2}(1)=0.49 \\
p=0.485\end{array}$ & $\begin{array}{c}\chi^{2}(4)=6.00 \\
p=0.199\end{array}$ \\
\hline Emergent surface area & $\begin{array}{c}\chi^{2}(4)=35.15 \\
p<0.001^{*}\end{array}$ & $\begin{array}{c}\chi^{2}(1)=0.18 \\
p=0.672\end{array}$ & $\begin{array}{c}\chi^{2}(4)=5.44 \\
p=0.246\end{array}$ \\
\hline Total epiphyte biomass & $\begin{array}{c}\chi^{2}(4)=18.44 \\
p=0.001^{*}\end{array}$ & $\begin{array}{c}\chi^{2}(1)=0.13 \\
p=0.716\end{array}$ & $\begin{array}{c}\chi^{2}(4)=6.53 \\
p=0.163\end{array}$ \\
\hline \multicolumn{4}{|l|}{ Traps } \\
\hline Total catch abundance & $\begin{array}{c}\chi^{2}(2)=0.45 \\
p=0.799\end{array}$ & $\begin{array}{c}\chi^{2}(1)=7.62 \\
p=0.006^{*}\end{array}$ & $\begin{array}{c}\chi^{2}(2)=11.94 \\
p=0.003^{*}\end{array}$ \\
\hline Species richness & $\begin{array}{c}\chi^{2}(2)=0.38 \\
p=0.827\end{array}$ & $\begin{array}{c}\chi^{2}(1)=0.12 \\
p=0.732\end{array}$ & $\begin{array}{c}\chi^{2}(2)=1.91 \\
p=0.385\end{array}$ \\
\hline \multicolumn{4}{|l|}{ Video } \\
\hline Total sightings & $\begin{array}{c}\chi^{2}(4)=24.79 \\
p<0.001^{*}\end{array}$ & $\begin{array}{c}\chi^{2}(1)=57.16 \\
p<0.001^{*}\end{array}$ & $\begin{array}{c}\chi^{2}(4)=36.35 \\
p<0.001^{*}\end{array}$ \\
\hline Species richness & $\begin{array}{c}\chi^{2}(4)=1.68 \\
p=0.794\end{array}$ & $\begin{array}{c}\chi^{2}(1)=0.15 \\
p=0.700\end{array}$ & $\begin{array}{c}\chi^{2}(4)=1.09 \\
p=0.859\end{array}$ \\
\hline Shiner perch sightings & $\begin{array}{c}\chi^{2}(4)=38.41 \\
p<0.001^{*}\end{array}$ & $\begin{array}{c}\chi^{2}(1)=62.01 \\
p<0.001^{*}\end{array}$ & $\begin{array}{c}\chi^{2}(4)=39.23 \\
p<0.001^{*}\end{array}$ \\
\hline $\begin{array}{l}\text { Pacific staghorn } \\
\text { sculpin sightings }\end{array}$ & $\begin{array}{c}\chi^{2}(4)=70.59 \\
p<0.001^{*}\end{array}$ & $\begin{array}{c}\chi^{2}(1)=14.28 \\
p<0.001^{*}\end{array}$ & $\begin{array}{c}\chi^{2}(4)=19.13 \\
p<0.001^{*}\end{array}$ \\
\hline Transiting behavior & $\begin{array}{c}\chi^{2}(4)=25.18 \\
p<0.001^{*}\end{array}$ & $\begin{array}{c}\chi^{2}(1)=55.13 \\
p<0.001^{*}\end{array}$ & $\begin{array}{c}\chi^{2}(4)=55.69 \\
p<0.001^{*}\end{array}$ \\
\hline Foraging behavior & $\begin{array}{c}\chi^{2}(4)=13.82 \\
p=0.008^{*}\end{array}$ & $\begin{array}{c}\chi^{2}(1)=0.00 \\
p=0.948\end{array}$ & $\begin{array}{c}\chi^{2}(4)=2.71 \\
p=0.608\end{array}$ \\
\hline
\end{tabular}


$z=4.564, \mathrm{p}<0.001$, transect position $\mathrm{E}: z=-3.452$, $\mathrm{p}=0.020$ ). In both cases, blade area at LL-E was significantly greater than that in the habitat to which it was compared. When multiplied by shoot density to estimate emergent surface area provided by eelgrass, transect position was significant (Table 1, Fig. 3). Emergent surface area generally increased from aquaculture habitats into eelgrass beds.

No significant difference in epiphyte load was detected across transect position or by aquaculture type (Table 1). However, as with blade surface area, multiplying epiphyte load by shoot density to estimate the total epiphyte biomass across the transect resulted in only transect position being significant, with higher total epiphyte biomass present in eelgrass habitat than in aquaculture (Table 1).

Average water temperature was approximately $18^{\circ} \mathrm{C}$, with little variation in time or space $(\mathrm{SE}=$ $0.35^{\circ} \mathrm{C}$ ). The water was about $1^{\circ} \mathrm{C}$ warmer in August than July (data from only 2 sites in July).

\subsection{Digital video}

Videos had an average Secchi contrast score of 14.6, with values ranging from 0 to 23.9 ( $\mathrm{SE}=0.79$ ). While the values themselves do not have any practical meaning, they give a sense of the range of visibility among the videos. The low values ( 0-8) represent videos in which the Secchi disk was barely visible at the $1 \mathrm{~m}$ distance. Videos with higher than average values have relatively clear visibility to a depth of field of $1 \mathrm{~m}$ and even slightly beyond. Videos were about $25 \%$ obstructed by eelgrass and algae on average, with values ranging from 0 to $67 \%$ (SE = 0.35). Neither visibility metric was highly correlated with total fish sightings in a given video (Secchi contrast: $\mathrm{R}=0.07$, eelgrass obstruction: $\mathrm{R}=0.17$ ) and were therefore not included in subsequent models.

Ten species of fish and crab were positively identified in 1299 sightings, with an additional 191 sightings in which no identification could be made (Table 2). Analysis of total fish and crab sightings in video data revealed that both transect position and aquaculture type and their interaction were significant (Tables 1 \& S5, Fig. 4). Pairwise comparisons of the interaction (Table S6) showed that sightings in the
LL aquaculture habitats (LL-A and LL-B) were both statistically greater than those for OB habitats (Fig. 4). For LLs, edge effects were detected, as sightings in habitats $30 \mathrm{~m}$ (LL-A) and $15 \mathrm{~m}$ (LL-B) into aquaculture and $30 \mathrm{~m}$ (LL-E) into eelgrass were all significantly greater than those at the LL edge (Fig. 4, Table S6). No significant difference in sightings of fauna was found between the edge and the other habitats for OB aquaculture. There were also no significant differences in species richness among the transect positions or between aquaculture types (Table 1).

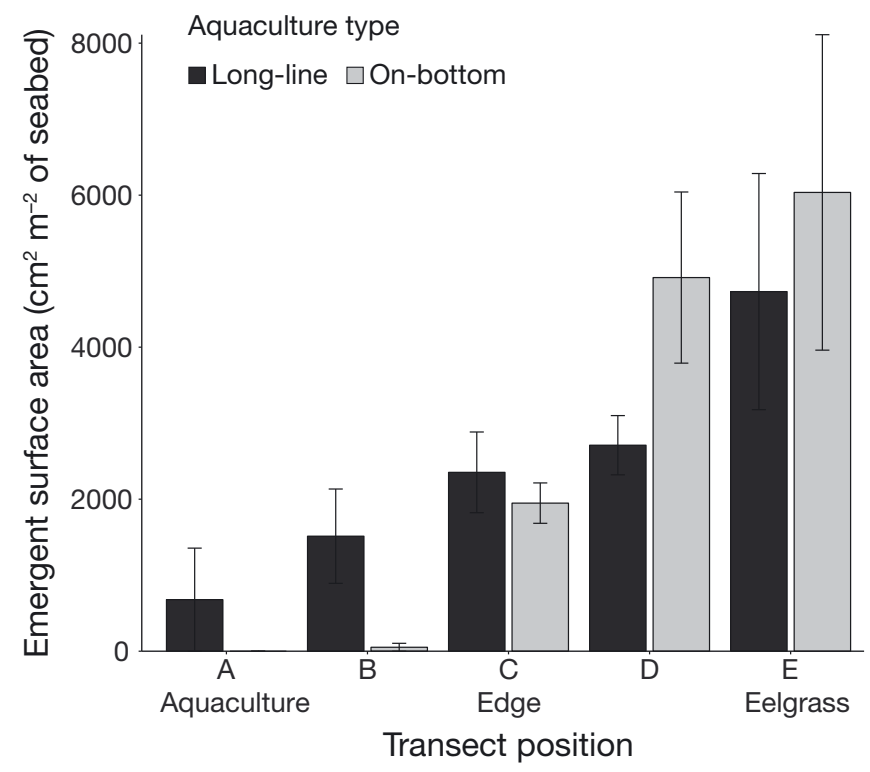

Fig. 3. Emergent surface area of Zostera marina, as calculated by blade surface area $\times$ shoot density for each aquaculture type and position along the transect $(\mathrm{N}=6)$. Error bars: $\pm 1 \mathrm{SE}$

Table 2. Species of fish and crabs sighted in underwater video footage and caught in minnow traps. Average size (SE) is also given for those measured in traps. Note: there were an additional 191 sightings that were unidentified. TL: total length; CW: carapace width

\begin{tabular}{|llccc|}
\hline Taxon & $\begin{array}{l}\text { Common } \\
\text { name }\end{array}$ & $\begin{array}{c}\text { Video } \\
\text { sightings }\end{array}$ & $\begin{array}{c}\text { Trap } \\
\text { catch }\end{array}$ & $\begin{array}{c}\text { Average } \\
\text { size }\end{array}$ \\
\hline Cymatogaster aggregata & Shiner perch & 675 & 5 & 43 (1.2) mm TL \\
Leptocottus armatus & Staghorn sculpin & 138 & 19 & 131 (2.3) mm TL \\
Gasterosteus aculeatus & Three-spine stickleback & 76 & 144 & \\
Metacarcinus magister & Dungeness crab & 30 & 50 & 26 (1.3) mm CW \\
Rhacochilus vacca & Pile perch & 29 & 0 & \\
Sygnathus leptorhyncus & Bay pipefish & 13 & 7 & \\
Parophrys vetulus & English sole & 6 & 3 & 94 (3.6) mm TL \\
Pholis ornata & Saddleback gunnel & 5 & 38 & \\
Ophiodon elongatus & Lingcod & 1 & 0 & \\
Aulorhyncus flavidus & Tubesnout & 1 & 0 & \\
Hemigrapsus oregonensis & Yellow shore crab & 0 & 3 & \\
Pagurus spp. & Hermit crab & 0 & 1 & \\
\hline
\end{tabular}




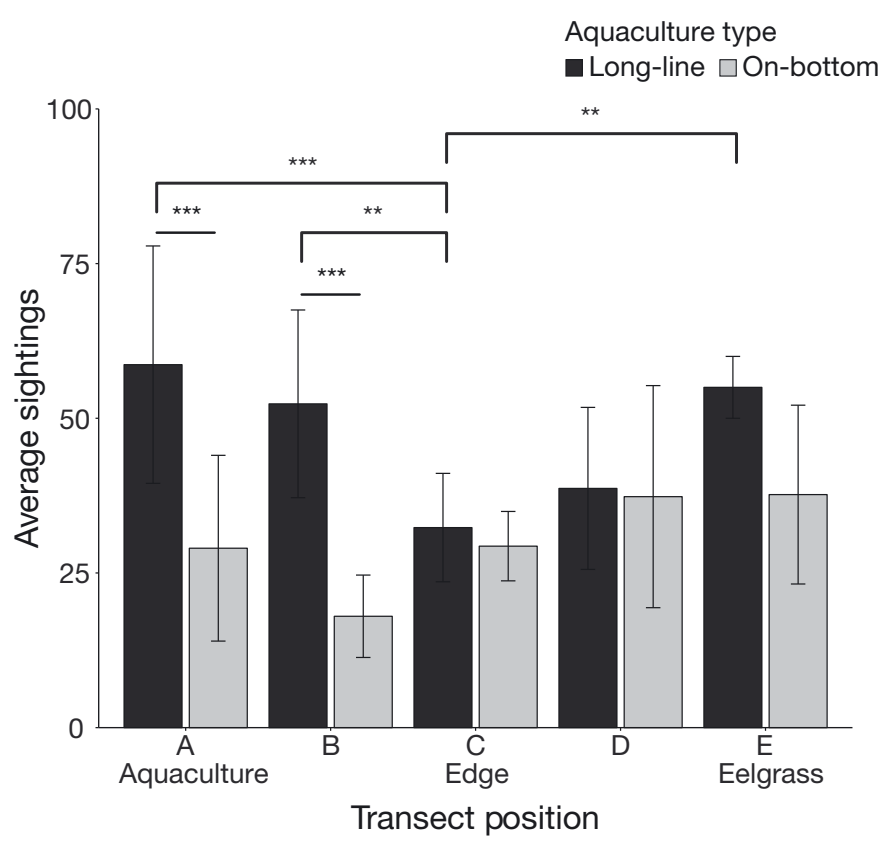

Fig. 4. Average $( \pm 1 \mathrm{SE})$ total sightings of fish and crabs from video data across transects and between aquaculture types $(\mathrm{N}=3)$. Brackets show significant contrasts of interest from simultaneous comparisons of all pairs (significance: ${ }^{* *} \mathrm{p}<0.01$; $\left.{ }^{* * *} \mathrm{p}<0.001\right)$

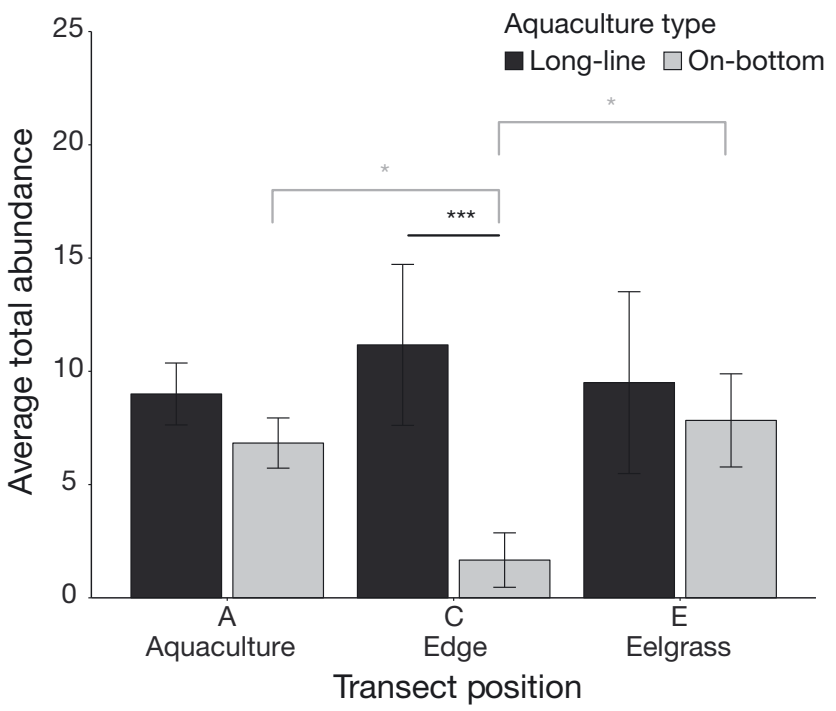

Fig. 5. Average $( \pm 1 \mathrm{SE})$ catch of fish and crabs in minnow traps across the transects and between aquaculture types $(\mathrm{N}=6)$. Brackets show significant contrasts of interest from simultaneous comparisons of all pairs significance: ${ }^{*} \mathrm{p}<0.05$; ${ }^{* * *} \mathrm{p}<0.001$

Shiner perch Cymatogaster aggregata (58\% of sightings) and Pacific staghorn sculpin Leptocottus armatus (12\% of sightings) sightings were each significantly related to both transect position and aquaculture type, along with their interaction (Table 1,
Figs. S3 \& S4). Dungeness crab Metacarcinus magister was the fourth most observed species in video and caught in traps (Table 2). They appeared most often in aquaculture habitats, especially OB culture (Fig. S5), but were not observed consistently enough to allow for informative statistical analyses. Post hoc comparisons indicated that shiner perch sightings in both LL aquaculture habitats (LL-A and LL-B) were significantly greater than in OB habitats (OB-A and OB-B; transect position $\mathrm{A}: \mathrm{Z}=-5.173, \mathrm{p}<0.001$, transect position $\mathrm{B}: z=-6.037, \mathrm{p}<0.001)$. In addition, sightings at the $\mathrm{OB}$ edge (OB-C) were significantly greater than those at the habitat $15 \mathrm{~m}$ into the aquaculture bed (OB-B; OB-B and OB-C: $z=4.188$, $\mathrm{p}<0.001)$. For Pacific staghorn sculpins, sightings in the LL habitat $15 \mathrm{~m}$ into the bed (LL-B) were significantly greater than in OB aquaculture (OB-B), but this was the only habitat where there was a significant difference (transect position B: $z=-3.512, \mathrm{p}=$ 0.013). On the LL transect, sightings in both of the aquaculture habitats (LL-A and LL-B) were significantly greater than those at the edge (LL-C; LL-A and LL-C: $z=-3.850, \mathrm{p}<0.01$, LL-B and LL-C: $z=$ $-4.241, \mathrm{p}<0.001)$.

Four behaviors were characterized for fish and crabs in the video: foraging, seeking refuge, schooling, and transiting. By far, the most common behavior observed was transiting (88\% of sightings). Both transect position and aquaculture type and their interaction were found to significantly affect the number of transiting sightings (Table 1), but transiting behavior tended to be lowest along the edge. This is consistent with the analysis of the complete data set. Post hoc analyses revealed the same patterns as the data set for all behaviors combined. Analysis of foraging observations (8\% of sightings) revealed that transect position was significant (Table 1), and again, foraging behavior trended highest in the structured habitats. Neither of the other behaviors were observed frequently enough to enable separate analyses.

\subsection{Minnow traps}

Nine species of fish and crab were caught in the minnow traps and mostly confirmed those observed in the video (Table 2). Both aquaculture type and the interaction between the 2 fixed factors were found to significantly affect the total number of fish caught (Tables 1 \& S7, Fig. 5).

Pairwise comparisons indicated a significant difference between total catch of fish and crab in aqua- 
culture types at the edge, with the LL edge (LL-C) being greater than the OB edge (Table S8), while there was no discernable difference between catch in eelgrass and aquaculture eelgrass habitats. The high average catch seen at LL-C was mainly driven by a large catch of three-spined sticklebacks Gasterosteus aculeatus at one site (Tokeland, 36 in LL$\mathrm{C}$ traps across both sampling points). Evidence of edge effects were most apparent in the OB aquaculture, as catches in both the aquaculture and eelgrass habitats were significantly greater than those at the edge (Table S8). No significant differences in species richness were detected across the transect or between aquaculture types (Table 1).

\subsection{PTUs}

Both treatment and check time significantly affected the presence of bait (Table 3), with the low treatment being preyed upon more and almost all of the bait absent at the $24 \mathrm{~h}$ check. Aquaculture type was also significant, with more predation in LL habitats, while there was no significant interaction with transect position (Fig. 6, Table 3).

\section{DISCUSSION}

The structural complexity of estuarine habitats is an important factor influencing the diversity and abundance of fauna, including fish and mobile invertebrates. Seagrass beds generally harbor higher diversity and abundance of these organisms versus open unstructured soft bottom habitat (Orth et al. 1984, Hughes et al. 2002, Horinouchi 2007, Ferraro \& Cole 2010). Patterns observed are often dependent on species, functional group, or even sampling device (Gross et al. 2017, 2018). Here, we sought to characterize the function of 2 forms of shellfish aqua-

Table 3. Analysis of deviance results following a generalized linear mixed model fit for the predation tethering unit data $(\mathrm{N}=3)$. Bold indicates significance $(\mathrm{p}<0.05)$

\begin{tabular}{|lrcc|}
\hline Fixed effect & $\chi^{2}$ & df & $\operatorname{Pr}\left(>\chi^{2}\right)$ \\
\hline Transect position & 5.7743 & 4 & 0.21665 \\
Aquaculture type & 6.3637 & 1 & $\mathbf{0 . 0 1 1 6 5}$ \\
Treatment & 57.8562 & 1 & $<\mathbf{0 . 0 0 1}$ \\
Check time & 330.5039 & 1 & $\mathbf{< 0 . 0 0 1}$ \\
Transect position $\times$ & 6.9406 & 4 & 0.13906 \\
aquaculture type & & & \\
\hline
\end{tabular}

culture as another structured habitat utilized by nekton and compare that with adjacent vegetated eelgrass Zostera marina habitat, with consideration of the edge habitat created between them. We found that fish use of off-bottom LL oyster aquaculture habitat was similar to that of eelgrass. In contrast, average sightings of fish in $\mathrm{OB}$ oyster aquaculture were significantly fewer than sightings in both LL aquaculture and eelgrass, which were statistically indistinct (Table 1, Fig. 4). These results may be related to differences in habitat structure, since there is often a positive relationship between habitat structure and fish abundance (Orth et al. 1984, Ferraro \& Cole 2010), and both LL oyster aquaculture and eelgrass beds have more habitat structure than OB oyster aquaculture (Fig. 3). Predation intensity measurements and observations of foraging activity in the video footage suggest that LL aquaculture supported predation and foraging rates analogous to those measured in eelgrass. Fish abundance at the edge between the LL aquaculture and eelgrass habitats was generally intermediate but was distinct at the edge between OB culture and eelgrass. This consideration of edges as separate habitat is especially relevant should shellfish aquaculture be expanded in these estuaries. Aquaculture type can affect the distribution of fish across the habitat transition into eelgrass-dominated habitat.

\subsection{Fish community}

More fish were sighted in LL aquaculture and eelgrass habitats than in OB aquaculture habitat, as evidenced by the significant interaction between transect position and aquaculture type in our generalized linear model. This finding indicates that aquaculture method influenced the distribution of the observed fish species across the habitat transition, supporting our expectations of structural effects on nekton. To date, there have been few studies directly comparing LL and OB aquaculture. Hosack et al. (2006) found few differences in mobile nekton community composition or abundance in eelgrass, OB culture, or open unstructured habitats in Willapa Bay sampled with fyke nets that integrated catch over a $24 \mathrm{~h}$ period. With the exception of shiner perch Cymatogaster aggergata, which were more abundant in eelgrass habitat, a similar lack of habitat differences was reported by Dumbauld et al. (2015), who used actively towed trawl nets in order to capture juvenile salmonids. Pinnix et al. (2005) deployed shrimp trawls and fyke nets adjacent to off-bottom oyster culture, 
A First check low by transect position and aquaculture type
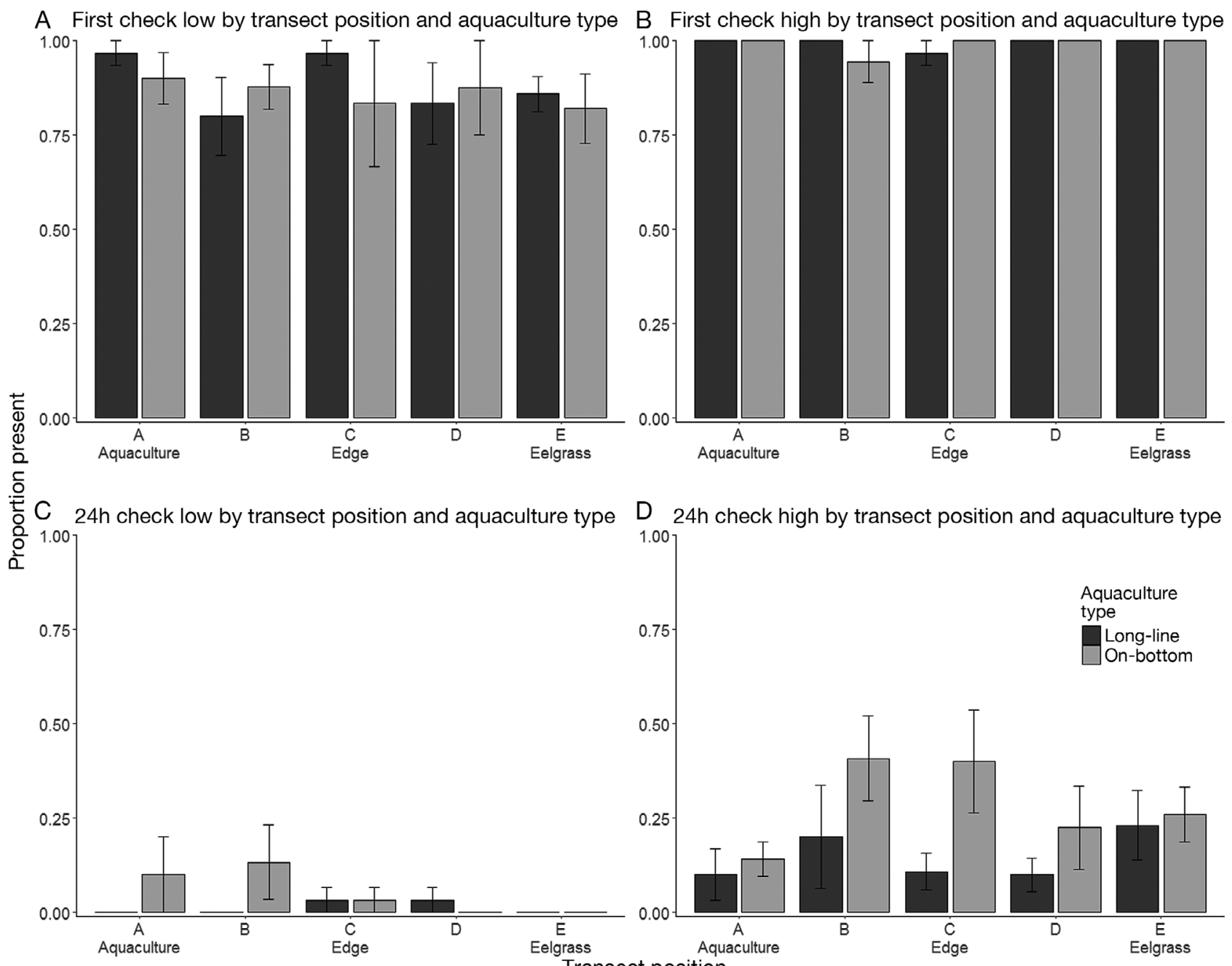

Fig. 6. Results of predation tethering unit arrays for both the $(A, C)$ low treatment and $(B, D)$ high treatment at the $(A, B)$ first check and $(\mathrm{C}, \mathrm{D}) 24 \mathrm{~h}$ check $(\mathrm{N}=6)$. Error bars: $\pm 1 \mathrm{SE}$

eelgrass, and open unvegetated mudflat habitats in Humboldt Bay, CA, and recorded higher species richness and higher catches adjacent to off-bottom culture habitat than either of the other 2 habitats. Off-bottom aquaculture also harbored a greater number of species than nearby eelgrass in an estuary in southern Rhode Island (DeAlteris et al. 2004). Although methods varied across these studies, trends in habitat use support the findings presented here.

The nekton community observed utilizing intertidal aquaculture and eelgrass habitats in our study was a subset of that documented as mesopredators in previous studies of these habitats in Willapa Bay and other estuaries along the US West Coast (Hosack et al. 2006, Hughes et al. 2014, Dumbauld et al. 2015, Gross et al. 2017). We caught fewer pelagic species and some of the less common taxa of nekton and attribute this primarily to differences in sampling gear and the total area sampled by our underwater video cameras. We used minnow traps to confirm the species seen in the video and provide a second data set to evaluate sampling discrepancies encountered when using video recording, like fish attraction to structures used to deploy cameras (Gross et al. 2018). While the species sampled were consistent, abundance of individual taxa sometimes differed between gear types. For example, the high catch of threespined sticklebacks Gasterosteus aculeatus at one site (Tokeland) was corroborated by frequent sightings of this species in video from that site, but more saddleback gunnels Pholis ornata, a cryptic species, were caught in traps than sighted in video from the same locations. Additionally, while Dungeness crab Metacarcinus magister appeared most frequently in 
OB culture habitat in both video and traps, as has been previously reported (reviewed in Dumbauld et al. 2009), we were less confident in these data for small crabs as they too have highly cryptic behavior in structured habitat. Thus, method considerations need to be carefully addressed when characterizing fish communities, particularly regarding management decisions.

While edge effects were not broadly apparent and congruous for both aquaculture methods, slightly fewer fish were observed at the edge. The lack of comprehensive statistical significance of edge effects could be due to the small sample size but perhaps also to the wide range of possible responses across species and time. Nonetheless, the visual trend in use of the observed species provides evidence that the habitat edge can influence species behavior. Edge sightings were significantly fewer than sightings in both the LL aquaculture and eelgrass interior habitats, suggesting that the edge provided less desirable habitat, potentially because of a higher predation risk or reduced food availability (Smith et al. 2011, Macreadie et al. 2012).

Responses of shiner perch and Pacific staghorn sculpins Leptocottus armatus, the 2 most sighted species in our study, further highlight potential driving mechanisms. Shiner perch were approximately equally abundant across the LL transect but were less abundant in OB aquaculture. Previous researchers have also documented higher abundance of shiner perch in eelgrass patches or on the edges of eelgrass beds relative to unvegetated sites (Dumbauld et al. 2015, Gross et al. 2017). In contrast, Pacific staghorn sculpins were found primarily in aquaculture habitats, especially LLs, and less frequently in interior eelgrass habitat. In Samish Bay (Washington, USA), Pacific staghorn sculpins were also sighted in underwater video more frequently in LL aquaculture and edge habitats than in eelgrass (Clarke 2017). The primary foraging behavior of each species may relate to contrasting use of edge habitats. Pacific staghorn sculpins have been recognized as avid predators of epibenthic invertebrates, juvenile fish, and insects, while shiner perch rely primarily on benthic polychaetes and other invertebrate mesograzers (Williams 1994, Troiano et al. 2013, McPeek et al. 2015, Whitney et al. 2017). Pacific staghorn sculpins make use of the refuge along the edge to capture prey, and shiner perch typically rely on the structure and food available in the interior of structured habitats. These differences in sightings may also relate to biases of the sampling method; shiner perch are often obvious swimming within the water column while Pacific staghorn sculpins swim along the bottom in a slow and cryptic manner and have previously been reported to be attracted to gear (Gross et al. 2018). Regardless, the marked differences in the distribution patterns of these 2 species highlight the complexities of edge effects between aquaculture and eelgrass.

\subsection{Habitat structure}

There was a clear increase in eelgrass habitat structure moving from both aquaculture habitats to eelgrass beds, as expected, given the sampling design, but the increase of eelgrass was less extreme on the LL transect than the OB transect (Fig. 3). This difference between aquaculture types is consistent with previous research that showed less impact of LL aquaculture on shoot density than OB culture, though both resulted in lower densities, and this difference was largely associated with mechanical harvest methods used in some OB culture areas (reviewed in Ferriss et al. 2019). Although we did not survey the growers to determine the most recent harvest event or method, all 3 OB culture beds we studied were previously classed as mechanical harvest (B. R. Dumbauld pers. obs). The LLs themselves also clearly provide vertical structure that contributes to the overall habitat complexity. DeAlteris et al. (2004) found that the emergent surface area $\left(\mathrm{cm}^{2} \mathrm{~m}^{-2}\right)$ of off-bottom aquaculture gear (racks) was comparable to that of eelgrass. Measurements of vertical structure provided by aquaculture gear would allow for a more complete understanding of the total structure that is potentially shaping the distribution of species across the habitat matrix.

The difference in eelgrass structure between aquaculture types also relates to the potential strength of edge effects between aquaculture and eelgrass beds. For both aquaculture types, the edge was defined based on where the aquaculture stopped; this did not always equate to the edge of the eelgrass bed. By this definition, the edge did not always represent a dramatic change in habitat. The type of edge (sharp vs. gradual transition) influences the magnitude of interactions shaping the distribution of marine mollusks across experimental landscapes, with edge effects being more pronounced when there was a sharper transition between aquaculture and adjacent habitat (Matias et al. 2013). The influence of the type of edge adds a layer of complexity to management of aquaculture and eelgrass, since the actual extent of eelgrass within an aquaculture bed changes over time 
(Dumbauld \& McCoy 2015). Further research could help to clarify how the sharpness of the edge affects habitat use.

\subsection{Predation and resource availability}

Results from our surveys using standardized PTUs were consistent with video sightings and provide evidence of greater levels of predation within the LL habitats than OB habitats for both treatments (Fig. 6). Increased predation intensity observed within the LL aquaculture is consistent with greater sightings of predatory fish (such as Pacific staghorn sculpins) and crabs in long-lines and suggests that the increased sightings were at least in part sightings of predators that consumed the bait. These patterns in bait consumption agree with those reported by Clarke (2017), who observed even higher loss of baits in Tillamook Bay, Oregon, but lower bait loss in Samish Bay, Washington, where she also observed fewer sculpins. Ruesink et al. (2019) reported a $70 \%$ loss of baits deployed in Willapa Bay for $24 \mathrm{~h}$ at the sediment surface during summer, with no difference in bait consumption between eelgrass and open mud habitats. Previous research suggests a potentially conflicting relationship between predation intensity and habitat structure. Some researchers have found that the presence of structure, but not the relative amount of structure, has an influence on prey survival (Mattila et al. 2008), while others have seen a clear decrease in predation risk with increased shoot density (Reynolds et al. 2018). This decrease is attributed to a reduction in detection and capture of mobile prey within more complex habitats. We saw an increase in predation with increasing habitat structure, suggesting that the complexity was not great enough to reduce detection of prey (i.e. bait).

Epiphytes on seagrass blades are known to be an important food source for epifauna or mesograzers within seagrass meadows (Jernakoff et al. 1996, Cullen-Unsworth \& Unsworth 2013, Hayduk et al. 2019) and some of these mesograzers in turn are fed upon by mesopredators, including juvenile salmon. Quantification of epiphyte percent cover and load therefore provides an estimate of food availability among the habitat types. Values for epiphyte load in this study fell within the ranges of those found in other bays along the West Coast of the USA (Clarke 2017, Hayduk et al. 2019). Epiphyte load did not significantly vary across the transect or between aquaculture types in our study, suggesting that the presence of aquaculture did not affect epiphyte abun- dance on eelgrass. When considering total epiphyte biomass available at the landscape level (i.e. by multiplying epiphyte load by eelgrass shoot density), we did detect lower abundances in the aquaculture habitats due to the lower presence of eelgrass within these habitats. We did not, however, measure epiphytes present on the aquaculture gear or oysters themselves, which have been shown to be abundant elsewhere and would increase total food available to mesograzers (DeAlteris et al. 2004, Erbland \& Ozbay 2008).

One of the advantages of using video as a sampling tool is the ability to make behavioral observations. We found that foraging behavior varied significantly by transect position, with less foraging occurring at the edge than in both interior habitats. In an Australian estuary, predators made use of edges between seagrass beds and open sand, while prey species were more common within the seagrass (Smith et al. 2011). These researchers found that predator presence along the edge may have discouraged foraging in this habitat. While observation of foraging in our study was limited (8\% of all sightings), sightings of a known predator (Pacific staghorn sculpin) were low on the edge between aquaculture and eelgrass. Thus, we suggest that a combination of food availability and predation risk (perhaps by larger predators like birds) influenced by habitat structure shaped the decrease in foraging observed at this edge, but further research should be conducted to clarify this result.

\section{CONCLUSIONS}

This research sought to compare the use of habitat created by 2 different oyster aquaculture methods with that of eelgrass, which is an important natural habitat for fish and mobile invertebrates in a US Pacific coast estuary. We found a clear difference in fish use of off-bottom (LL) and OB oyster culture habitats, but edge effects were less distinct. The effect of structured habitat was species-specific, as had previously been observed for eelgrass, with 2 of the most abundant species, shiner perch Cymatogaster aggergata and Pacific staghorn sculpin Leptocottus armatus differing in their response.

Federal and state regulations currently prohibit the establishment of new aquaculture beds within native eelgrass and establish buffer zones around these eelgrass beds due to the recognized value of this structured habitat as a nursery for juvenile fish and invertebrates. For example, the US Army Corps of Engineers, with input from the NOAA National 
Marine Fisheries Service, prohibits new aquaculture within a 16 horizontal foot buffer around eelgrass, while a buffer of $25-30$ feet $(7.6-9.1 \mathrm{~m})$ is suggested under the Magnuson-Stevens Act (Pacific Fishery Management Council 2014, US Army Corps of Engineers 2017). While existing aquaculture is generally excluded from these regulations, the habitat provided by aquaculture itself is not valued, and this precautionary approach to expansion is based solely on autecology of eelgrass and value to other resources. Our results suggest that the type of aquaculture and structure it provides influences its functional value as estuarine habitat and that it is comparable to eelgrass for some resources. The type of aquaculture may also affect the breadth and strength of edge effects at larger scales and could inform concerns about eelgrass bed fragmentation and be a foundation for setting scientifically appropriate buffer widths between habitats. In addition, studies such as this could inform best management practices for shellfish aquaculture, which is increasingly being recognized as a beneficial use of US coastal waters (NOAA 2018). As the industry is expected to grow in the coming years, it is necessary to understand how that growth impacts estuarine function. Expanding the knowledge base concerning similarities between shellfish aquaculture and eelgrass will give managers tools to appropriately balance these 2 stakeholder interests.

Acknowledgements. This work was funded in part by 2 NOAA NMFS Saltonstall-Kennedy grants (2014/2015 NOAA-NMFS-FHQ-2015-2004246 and 2016/2017 NA16 NMF4270254), a 2016-2018 Oregon State University Agricultural Research Foundation grant to F.T., and project funds of the USDA Agricultural Research Service (CRIS Project 2072-63000-004-00D). Field and laboratory support were provided by D. Mercer, J. Minch, A. Blanchette, and G. Schwinge. Additional thanks to S. Heppell for support in developing the analysis.

\section{LITERATURE CITED}

Baker P (1995) Review of ecology and fishery of the Olympia oyster, Ostrea lurida with annotated bibliography. J Shellfish Res 14:501-518

Bates D, Maechler M, Bolker B, Walker S (2015) Fitting linear mixed-effects models using lme4. J Stat Softw 67:1-48

*Beck MW, Heck KL Jr, Able KW, Childers DL and others (2001) The identification, conservation, and management of estuarine and marine nurseries for fish and invertebrates. Bioscience 51:633

Bell SS, Brooks RA, Robbins BD, Fonseca MS, Hall MO (2001) Faunal response to fragmentation in seagrass habitats: implications for seagrass conservation. Biol Conserv 100:115-123

Bolker BM, Brooks ME, Clark CJ, Geange SW, Poulsen JR,
Stevens MHH, White JSS (2009) Generalized linear mixed models: a practical guide for ecology and evolution. Trends Ecol Evol 24:127-135

* Bologna PAX, Heck KL Jr (2002) Impact of habitat edges on density and secondary production of seagrass-associated fauna. Estuaries 25:1033-1044

* Boström C, Jackson EL, Simenstad CA (2006) Seagrass landscapes and their effects on associated fauna: a review. Estuar Coast Shelf Sci 68:383-403

*Boström C, Pittman S, Simenstad C, Kneib R (2011) Seascape ecology of coastal biogenic habitats: advances, gaps, and challenges. Mar Ecol Prog Ser 427:191-217

Bowden DA, Rowden AA, Attrill MJ (2001) Effect of patch size and in-patch location on the infaunal macroinvertebrate assemblages of Zostera marina seagrass beds. J Exp Mar Biol Ecol 259:133-154

* Castel J, Labourg PJ, Escaravage V, Auby I, Garcia ME (1989) Influence of seagrass beds and oyster parks on the abundance and biomass patterns of meio- and macrobenthos in tidal flats. Estuar Coast Shelf Sci 28:71-85

Clarke L (2017) Functional comparison of longline oyster aquaculture and eelgrass (Zostera marina L.) habitats among Pacific Northwest estuaries, USA. MS thesis, Oregon State University, Corvallis, OR

* Costanza R, d'Arge R, de Groot R, Faber S and others (1997) The value of the world's ecosystem services and natural capital. Nature 387:253-260

Cullen-Unsworth L, Unsworth R (2013) Seagrass meadows, ecosystem services, and sustainability. Environment 55: $14-28$

DeAlteris JT, Kilpatrick BD, Rheault RB (2004) A comparative evaluation of the habitat value of shellfish aquaculture gear, submerged aquatic vegetation and a non-vegetated seabed. J Shellfish Res 23:867-874

*Duffy JE, Ziegler SL, Campbell JE, Bippus PM, Lefcheck JS (2015) squidpops: a simple tool to crowdsource a global map of marine predation intensity. PLOS ONE 10: e0142994

* Dumbauld BR, McCoy LM (2015) Effect of oyster aquaculture on seagrass Zostera marina at the estuarine landscape scale in Willapa Bay, Washington (USA). Aquacult Environ Interact 7:29-47

*Dumbauld BR, Ruesink JL, Rumrill SS (2009) The ecological role of bivalve shellfish aquaculture in the estuarine environment: a review with application to oyster and clam culture in West Coast (USA) estuaries. Aquaculture 290:196-223

* Dumbauld BR, Hosack GR, Bosley KM (2015) Association of juvenile salmon and estuarine fish with intertidal seagrass and oyster aquaculture habitats in a Northeast Pacific estuary. Trans Am Fish Soc 144:1091-1110

Eggleston DB, Etherington LL, Elis WE (1998) Organism response to habitat patchiness: species and habitatdependent recruitment of decapod crustaceans. J Exp Mar Biol Ecol 223:111-132

Erbland PJ, Ozbay G (2008) A comparison of the macrofaunal communities inhabiting a Crassostrea virginica oyster reef and oyster aquaculture gear in Indian River Bay, Delaware. J Shellfish Res 27:757-768

KEwers RM, Thorpe S, Didham RK (2007) Synergistic interactions between edge and area effects in a heavily fragmented landscape. Ecology 88:96-106

* Ferraro SP, Cole FA (2007) Benthic macrofauna-habitat associations in Willapa Bay, Washington, USA. Estuar Coast Shelf Sci 71:491-507 
Ferraro SP, Cole FA (2010) Ecological periodic tables for nekton usage of four US Pacific Northwest estuarine habitats. Can J Fish Aquat Sci 67:1957-1967

Ferrell DJ, Bell JD (1991) Differences among assemblages of fish associated with Zostera capricorni and bare sand over a large spatial scale. Mar Ecol Prog Ser 72:15-24

Ferriss BE, Conway-Cranos LL, Sanderson BL, Hoberecht L (2019) Bivalve aquaculture and eelgrass: a global metaanalysis. Aquaculture 498:254-262

Forman RTT, Godron M (1986) Landscape ecology. John Wiley \& Sons, New York, NY

Friard O, Gamba M (2016) BORIS: a free, versatile opensource event-logging software for video/audio coding and live observations. Methods Ecol Evol 7:1325-1330

Gates JE, Mosher JA (1981) A functional approach to estimating habitat edge width for birds. Am Midl Nat 105:189-192

* Gross C, Donoghue C, Pruitt C, Trimble AC, Ruesink JL (2017) Taxonomic and functional assessment of mesopredator diversity across an estuarine habitat mosaic. Ecosphere 8:e01792

Gross C, Donoghue C, Pruitt C, Ruesink JL (2018) Habitat use patterns and edge effects across a seagrass-unvegetated ecotone depend on species-specific behaviors and sampling methods. Mar Ecol Prog Ser 598:21-33

Gross C, Ruesink JL, Pruitt C, Trimble AC, Donoghue C (2019) Temporal variation in intertidal habitat use by nekton at seasonal and diel scales. J Exp Mar Biol Ecol 516:25-34

Hayduk JL, Hacker SD, Henderson JS, Tomas F (2019) Evidence for regional-scale controls on eelgrass (Zostera marina) and mesograzer community structure in upwelling-influenced estuaries. Limnol Oceanogr 64: 1120-1134

Heck KL Jr, Hays G, Orth RJ (2003) Critical evaluation of the nursery role hypothesis for seagrass meadows. Mar Ecol Prog Ser 253:123-136

Hedgpeth JW, Obrebski S (1981) Willapa Bay: a historical perspective and a rationale for research. Office of Biological Services, US Fish and Wildlife Service, Washington, DC

Holsman KK, McDonald PS, Armstrong DA (2006) Intertidal migration and habitat use by subadult Dungeness crab Cancer magister in a NE Pacific estuary. Mar Ecol Prog Ser 308:183-195

Horinouchi M (2007) Review of the effects of within-patch scale structural complexity on seagrass fishes. J Exp Mar Biol Ecol 350:111-129

Hosack GR, Dumbauld BR, Ruesink JL, Armstrong DA (2006) Habitat associations of estuarine species: comparisons of intertidal mudflat, seagrass (Zostera marina), and oyster (Crassostrea gigas) habitats. Estuaries Coasts 29:1150-1160

Hothorn T, Bretz F, Westfall P (2008) Simultaneous inference in general parametric models. Biom J 50:346-363

Hovel KA, Lipcius RN (2001) Habitat fragmentation in a seagrass landscape: patch size and complexity control blue crab survival. Ecology 82:1814-1829

Hughes JE, Deegan LA, Wyda JC, Weaver MJ, Wright A (2002) The effects of eelgrass habitat loss on estuarine fish communities of southern New England. Estuaries 25: 235-249

Hughes BB, Levey MD, Brown JA, Fountain MC and others (2014) Nursery functions of US West Coast estuaries: the state of knowledge for juveniles of focal invertebrate and fish species. The Nature Conservancy, Arlington, VA
Jelbart JE, Ross PM, Connolly RM (2006) Edge effects and patch size in seagrass landscapes: an experimental test using fish. Mar Ecol Prog Ser 319:93-102

Jenkins GP, May HMA, Wheatley MJ, Holloway MG (1997) Comparison of fish assemblages associated with seagrass and adjacent unvegetated habitats of Port Phillip Bay and Corner Inlet, Victoria, Australia, with emphasis on commercial species. Estuar Coast Shelf Sci 44: 569-588

Jernakoff P, Brearley A, Nielsen J (1996) Factors affecting grazer-epiphyte interactions in temperate seagrass meadows. Oceanogr Mar Biol Annu Rev 34:109-162

Jones CG, Lawton JH, Shachak M (1994) Organisms as ecosystem engineers. Oikos 69:373

Keenleyside MHA (1955) Some aspects of the schooling behaviour of fish. Behaviour 8:183-248

Lindsay CE, Simons D (1997) The fisheries for Olympia oysters, Ostreola canchaphila; Pacific oysters, Crassostrea gigas; and Pacific razor clams, Siliqua patula, in the State of Washington. In: Mackenzie CLJ, Burrell VGJ, Rosenfield A, Hobart WL (eds) The history, present condition, and future of the molluscan fisheries of North and Central America and Europe. NOAA, US Department of Commerce, Seattle, WA, p 89-113

Lotze HK, Lenihan HS, Bourque BJ, Bradbury RH and others (2006) Depletion, degradation, and recovery potential of estuaries and coastal seas. Science 312: 1806-1809

Macreadie PI, Hindell JS, Keough MJ, Jenkins GP, Connolly RM (2010) Resource distribution influences positive edge effects in a seagrass fish. Ecology 91:2013-2021

Macreadie P, Geraldi N, Peterson C (2012) Preference for feeding at habitat edges declines among juvenile blue crabs as oyster reef patchiness increases and predation risk grows. Mar Ecol Prog Ser 466:145-153

Matias MG, Coleman RA, Hochuli DF, Underwood AJ (2013) Macrofaunal responses to edges are independent of habitat-heterogeneity in experimental landscapes. PLOS ONE 8: e61349

*Mattila J, Heck KL Jr, Millstein E, Miller E, Gustafsson C, Williams S, Byron D (2008) Increased habitat structure does not always provide increased refuge from predation. Mar Ecol Prog Ser 361:15-20

McPeek KC, McDonald PS, VanBlaricom GR (2015) Aquaculture disturbance impacts the diet but not ecological linkages of a ubiquitous predatory fish. Estuaries Coasts $38: 1520-1534$

Nagelkerken I, Sheaves M, Baker R, Connolly RM (2015) The seascape nursery: a novel spatial approach to identify and manage nurseries for coastal marine fauna. Fish Fish 16:362-371

NNMFS (2016) Annual commercial landings statistics. https:// foss.nmfs.noaa.gov/apexfoss/f?p=215:200 (accessed 18 January 2018)

NOAA (2011) Marine aquaculture policy. National Oceanic and Atmospheric Administration, Washington, DC

NOAA (2018) National Shellfish Initiative Fact Sheet. National Oceanic and Atmospheric Administration, Washington, DC

* Olson AM, Hessing-Lewis M, Haggarty D, Juanes F (2019) Nearshore seascape connectivity enhances seagrass meadow nursery function. Ecol Appl 29:e01897

* Orth RJ, Moore KA (1986) Seasonal and year-to-year variations in growth of Zostera marina L. (eelgrass) in the lower Chesapeake Bay. Aquat Bot 24:335-341 
Orth RJ, Heck KL Jr, van Montfrans J (1984) Faunal communities in seagrass beds: a review of the influence of plant structure and prey characteristics on predator-prey relationships. Estuaries 7:339-350

Orth RJ, Carruthers TJB, Dennison WC, Duarte CM and others (2006) A global crisis for seagrass ecosystems. Bioscience 56:987-996

Pacific Fishery Management Council (2014) Appendix A to the Pacific Coast Salmon Fishery Management Plan: identification and description of essential fish habitat, adverse impacts, and recommended conservation measures for salmon. Pacific Fishery Management Council, Portland, OR

Pinna S, Sechi N, Ceccherelli G (2013) Canopy structure at the edge of seagrass affects sea urchin distribution. Mar Ecol Prog Ser 485:47-55

Pinnix WD, Shaw TA, Acker KC, Hetrick NJ (2005) Fish communities in eelgrass, oyster culture and mudflat habitats of north Humboldt Bay, California. Technical Report 2. US Fish and Wildlife Service, Arcata, CA

R Core Team (2016) R: a language and environment for statistical computing. R Foundation for Statistical Computing, Vienna

Reynolds PL, Stachowicz JJ, Hovel K, Boström C and others (2018) Latitude, temperature, and habitat complexity predict predation pressure in eelgrass beds across the Northern Hemisphere. Ecology 99:29-35

Robinson AM (1997) Molluscan fisheries in Oregon: Past, present, and future. In: Mackenzie CLJ, Burrell VGJ, Rosenfield A, Hobart WL (eds) The history, present condition, and future of the molluscan fisheries of North and Central America and Europe. NOAA, US Department of Commerce, Seattle, WA, p 89-113

Rooper CN, Gunderson DR, Armstrong DA (2003) Patterns in use of estuarine habitat by juvenile English sole (Pleuronectes vetulus) in four eastern North Pacific estuaries. Estuaries 26:1142-1154

Ruesink JL, Feist BE, Harvey CJ, Hong JS, Trimble AC, Wisehart LM (2006) Changes in productivity associated with four introduced species: ecosystem transformation of a 'pristine' estuary. Mar Ecol Prog Ser 311: 203-216

Ruesink JL, Hong JS, Wisehart L, Hacker SD, Dumbauld BR, Hessing-Lewis M, Trimble AC (2010) Congener comparison of native (Zostera marina) and introduced ( $Z$. japonica) eelgrass at multiple scales within a Pacific Northwest estuary. Biol Invasions 12:1773-1789

Ruesink JL, Gross C, Pruitt C, Trimble AC, Donoghue C (2019) Habitat structure influences the seasonality of nekton in seagrass. Mar Biol 166:75

Schaalje GB, McBride JB, Fellingham GW (2002) Adequacy of approximations to distributions of test statistics in complex mixed linear models. J Agric Biol Environ Stat $7: 512$

Selgrath JC, Hovel KA, Wahle RA (2007) Effects of habitat edges on American lobster abundance and survival. J Exp Mar Biol Ecol 353:253-264

Shaw WN (1997) The shellfish industry of California - past, present, and future. In: Mackenzie CLJ, Burrell VGJ, Rosenfield A, Hobart WL (eds) The history, present condition, and future of the molluscan fisheries of North and Central America and Europe. NOAA, US Department of Commerce, Seattle, WA, p 89-113

Sheaves M, Baker R, Nagelkerken I, Connolly RM (2015) True value of estuarine and coastal nurseries for fish: incorporating complexity and dynamics. Estuaries Coasts 38:401-414

* Simenstad CA, Fresh KL (1995) Influence of intertidal aquaculture on benthic communities in Pacific Northwest estuaries: scales of disturbance. Estuaries 18:43-70

Sisk TD, Haddad NM (2002) Incorporating the effects of habitat edges into landscape models: effective area models for cross-boundary management. In: Liu JG, Taylor WW (eds) Integrating landscape ecology into natural resource management. Cambridge University Press, Cambridge, p 208-240

* Skinner MA, Courtenay SC, McKindsey CW (2013) Reductions in distribution, photosynthesis, and productivity of eelgrass Zostera marina associated with oyster Crassostrea virginica aquaculture. Mar Ecol Prog Ser 486:105-119

Smith TM, Hindell JS, Jenkins GP, Connolly RM (2008) Edge effects on fish associated with seagrass and sand patches. Mar Ecol Prog Ser 359:203-213

Smith TM, Hindell JS, Jenkins GP, Connolly RM (2010) Seagrass patch size affects fish responses to edges. J Anim Ecol 79:275-281

Smith TM, Hindell JS, Jenkins GP, Connolly RM, Keough MJ (2011) Edge effects in patchy seagrass landscapes: the role of predation in determining fish distribution. J Exp Mar Biol Ecol 399:8-16

* Tallis HM, Ruesink JL, Dumbauld B, Hacker S, Wisehart LM (2009) Oysters and aquaculture practices affect eelgrass density and productivity in a Pacific Northwest estuary. J Shellfish Res 28:251-261

* Tanner JE (2005) Edge effects on fauna in fragmented seagrass meadows. Austral Ecol 30:210-218

* Thom RM, Borde AB, Rumrill S, Woodruff DL, Williams GD, Southard JA, Sargeant SL (2003) Factors influencing spatial and annual variability in eelgrass (Zostera marina L.) meadows in Willapa Bay, Washington, and Coos Bay, Oregon, estuaries. Estuaries 26:1117-1129

* Troiano AT, King KA, Grue CE, Grassley JM, Ekblad CJ (2013) Brain acetylcholinesterase activity in shiner perch (Cymatogaster aggregata) and juvenile Chinook salmon (Oncorhynchus tshawytscha) after application of carbaryl to control burrowing shrimp within Willapa Bay, Washington. Arch Environ Contam Toxicol 65: 779-789

Turner MG (1989) Landscape ecology: the effect of pattern on process. Annu Rev Ecol Syst 20:171-197

US Army Corps of Engineers (2017) Chapter IX: aquaculture. www.nws.usace.army.mil/Missions/Civil-Works/ Regulatory/Permit-Guidebook/ (accessed 29 March 2018)

Wagner E, Dumbauld BR, Hacker SD, Trimble AC, Wisehart LM, Ruesink JL (2012) Density-dependent effects of an introduced oyster, Crassostrea gigas, on a native intertidal seagrass, Zostera marina. Mar Ecol Prog Ser 468: 149-160

Walton WC, Davis JE, Chaplin GI, Rikard FS, Hanson TR, Waters PJ, Swann DL (2012) Off-bottom oyster farming. Timely information: agriculture and natural resources. Fisheries and Aquaculture Series, Alabama Cooperative Extension System, Huntsville, AL

Whitney EJ, Beaudreau AH, Duncan DH (2017) Spatial and temporal variation in the diets of Pacific staghorn sculpins related to hydrological factors in a glacially influenced estuary. Trans Am Fish Soc 146:1156-1167

*Wiens JA, Milne BT (1989) Scaling of 'landscapes' in landscape ecology, or, landscape ecology from a beetle's perspective. Landsc Ecol 3:87-96 
Williams GD (1994) Effects of habitat modification on distribution and diets of intertidal fishes in Grays Harbor Estuary, Washington. MS thesis, University of Washington, Seattle, WA

Wisehart LM, Dumbauld BR, Ruesink JL, Hacker SD (2007) Importance of eelgrass early life history stages in response to oyster aquaculture disturbance. Mar Ecol Prog Ser 344:71-80

Editorial responsibility: Pablo Arechavala-Lopez,

Esporles, Illes Balears, Spain
Wright JT, Byers JE, Devore JL, Sotka EE (2014) Engineering or food? mechanisms of facilitation by a habitatforming invasive seaweed. Ecology 95:2699-2706

* Zhang PD, Liu YS, Guo D, Li WT, Zhang Q (2016) Seasonal variation in growth, morphology, and reproduction of eelgrass Zostera marina on the eastern coast of the Shandong Peninsula, China. J Coast Res 32: 315-322

Submitted: September 30, 2019; Accepted: September 14, 2020 Proofs received from author(s): November 17, 2020 